EXPLORING HOW FEMALE PUBLIC RELATIONS MANAGERS IN HIGHEREDUCATION INSTITUTIONS GAIN INFLUENCE

A Thesis Proposal
presented to
the Faculty of the Graduate School
at the University of Missouri
In Partial Fulfillment
of the Requirements for the Degree
Master of Arts
Dr. María Len-Ríos, Thesis Supervisor
DECEMBER 2013
beSS


(C) Copyright by Jesslyn Chew 2013

All Rights Reserved 
The undersigned, appointed by the dean of the Graduate School, have examined the thesis entitled

\section{EXPLORING HOW FEMALE PUBLIC RELATIONS MANAGERS IN HIGHER-EDUCATION INSTITUTIONS GAIN INFLUENCE}

presented by Jesslyn Chew,

a candidate for the degree of master of arts, and hereby certify that, in their opinion, it is worthy of acceptance.

Associate Professor María E. Len-Ríos

Professor Glen Cameron

Associate Professor Yong Volz

Associate Professor Debbie Dougherty 


\section{ACKNOWLEDGEMENTS}

I would like to thank my adviser, Dr. María E. Len-Ríos, for her guidance as I wrote this thesis. She consistently challenged me to produce my best work. I also appreciate the thoughtful input of my committee members, Dr. Glen Cameron, Dr. Yong Volz and Dr. Debbie Dougherty. I gleaned much from their scholarly expertise.

Two faculty members at my undergraduate alma mater, Truman State University, inspired me to pursue a graduate education. Dr. Diane Johnson and Dr. Marilyn Yaquinto, thank you for investing time and energy into mentoring me. I wouldn’t be where I am today without your encouragement and guidance.

I would be remiss if I did not acknowledge my supervisor, Mary Jo Banken. I have learned much about practicing public relations at a higher-education institution from watching her in action. Thank you for providing me the opportunity to further my professional and academic careers simultaneously. 


\section{TABLE OF CONTENTS}

ACKNOWLEDGEMENTS ........................................................... ii

ABSTRACT .............................................................................

Chapter

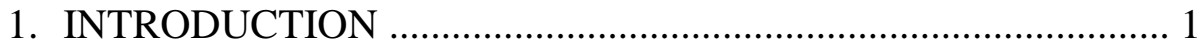

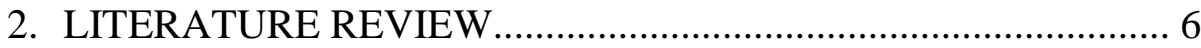

Female Practitioners' Presence in Management

Structuralist Perspective of Gender, Power and Organizations

Feminist Standpoint Theory

Power and Influence in PR

Berger's Types of Power

Additional Sources of Power

Power as a Function of Practitioner's Assigned and Perceived Roles

Understanding Female PR Practitioners' Ascent to Management

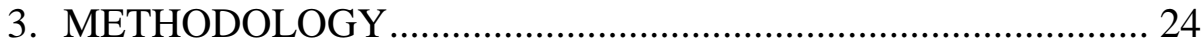

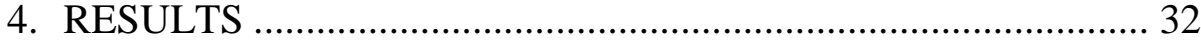

Power and Influence: Subtle Differences Shaped by Connotations

What Gives Individuals Influence?

Facilitating and Maintaining Relationships

Issues/Crisis Management

Personal Characteristics: Honesty, Decisiveness and Tenacity

Challenges to Career Success: Balancing Work and Family Obligations 
Challenges of Working in Higher Education

Rewards of Working in Higher Education

Moving Forward: Advice for the Next Generation of Female PR Managers in Higher-Education Institutions

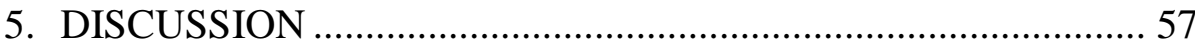

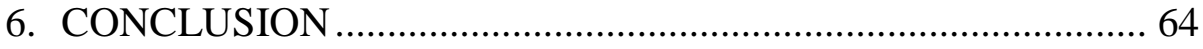

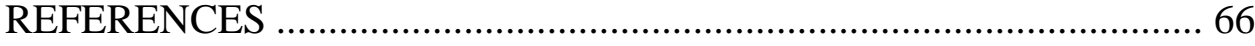

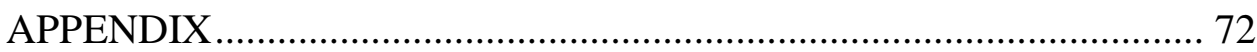

1. QUESTIONS FOR FEMALE PUBLIC RELATIONS MANAGERS 


\begin{abstract}
This study explored how female public relations (PR) managers working in higher-education institutions perceive that they gain influence in their jobs as communicators. To this end, the researcher conducted 12 semi-structured interviews with female, senior-level, PR professionals who work in colleges and universities. Using thematic analysis (Lindlof \& Taylor, 2002), the researcher uncovered that female PR managers gain influence in the higher-education setting through collaborative relationships, managing issues/crises and through their personality characteristics of honesty, decisiveness and tenacity. Although they have management positions, the women who were interviewed remained outnumbered in male-dominated highereducation administration and lacked advanced degrees possessed by many other college and university leaders. Feminist standpoint theory (Hartsock, 1983), which emphasizes studying power relations from the perspectives of marginalized individuals, guided this study. The participants have proven themselves in crisis communication yet still lack influence in strategic decision-making, which suggests further change is needed to move them beyond their roles as crisis communicators to become trusted counselors during their institutions' strategic planning and policy-making. When female PR managers have consistent seats at their higher-education institutions' decision-making tables, their influence can grow.
\end{abstract}




\section{INTRODUCTION}

PR professionals often are misunderstood and underappreciated by business and organization leaders, although communicators' reputations have improved in recent decades as they have asserted their value as technicians and managers (Berger \& Reber, 2005; Bowen, 2007). Even with improving reputations, communicators remain marginalized and underrepresented on organizations' decision-making teams, or dominant coalitions. Dominant coalitions increasingly include PR professionals, but typically only when PR expertise is relevant to the decisions at hand, such as during organizational crises when leaders need to communicate effectively with important stakeholders and the media (Grunig, 1992; Grunig, 2006). Data reporting how many practitioners have full membership in dominant coalitions is lacking; however, recent research concluded that about 65 percent of practitioners reported advising the dominant coalitions in their organizations (Bowen, 2007).

Previous research (Spicer, 1997) has evaluated the marginalization of PR practitioners within organizations, but research examining how gender might exacerbate the marginalization of practitioners and the profession remains limited. Feminist scholars (Hartsock, 1981, 1983; Buzzanell, 1992) have asserted women continue to be marginalized in workplaces, and some scholars (Lauzen \& Dozier, 1992; Rakow, 1989) have suggested that since women dominate the PR industry, the industry also is marginalized. 
PR practitioners' struggles to be included in decision-making teams is not unlike the challenges women encounter when they assume leadership positions in PR and in other industries, such as those in science, technology, engineering and math (STEM). Men typically dominate STEM fields, which may explain women's struggle. Yet, even in female-dominated fields, such as nursing, women may have lower statuses and receive less pay compared to men who also work in nursing (Jones \& Gates, 2004). Furthermore, men working in "female" professions reported their gender gave them an advantage in hiring and promotion decisions (Williams, 1992). Stereotypical biases and cultural and organizational structures are at fault for the marginalization of women and the professions they dominate (Kanter, 1976, 1977).

Women are well represented in the workforce, yet American men still hold the majority of management positions in organizations. A 2011 Forbes article notes that, despite the fact women's presence in middle-management positions is growing, women CEOs lead less than 3 percent of U.S. Fortune 500 companies. Although PR is a femaledominated profession, men hold most top positions. In fact, a 2010 Public Relations Society of America report shows nearly 85 percent of PR practitioners are women, yet men represent 80 percent of top management positions. In addition, women communicators earn less than males at the same organizational levels, which is consistent with pay differences between men and women in other industries (Ragan, 2010).

Prior research has looked at how gender affects female PR managers' influence in business and organizational settings. However, work addressing how female communicators within higher-education institutions gain influence remains limited. 
Nonetheless, research examining women's involvement in higher-education administration found the academic environment to be more favorable to men's career advancement (White, Riordan, Ozkanli \& Neale, 2010; Ballenger, 2010). In addition, colleges and universities have been resistant to increase women's participation in administration (American Council on Education, 2007). This research may suggest female PR managers working in higher-education institutions face distinct sets of challenges worthy of further investigation. Examining the experiences of female practitioners who work in higher education will help illuminate how they gain influence in the male-dominated environments of college and university administration.

Organizational structure is one reason attributed to keeping women out of management (Kanter 1976, 1977). For instance, exclusion from influential networks, a lack of mentors, and male-dominated organizational environments contribute to the marginalization of female PR practitioners in organizations (Hon, 1995). In addition, female communicators most often hold low-level positions as technicians, and these positions limit their inclusion in strategic decision-making and access to decision-makers (Toth et al., 1988).

Discussions of power and influence undergird the examination of women's absence in PR management, and this study sought to contribute to existing literature in this area. Berger's (2005) formulations of power-over, power-with and power-to relations will provide the framework for discussions of power in this study because of their gendered characterizations. Power-over refers to authoritative, masculine expressions of power while power-with refers to relationship-focused, feminine expressions of power. 
Power-to relations refer to power that seeks to challenge and counteract gendered expressions of power through activism.

The forces that contribute to women practitioners' influence are varied and complex, and the purpose of this study was to explore how female PR managers perceive they have gained power as senior-level communicators. Used together, Berger's (2005) forms of power and feminist standpoint theory provide a more complete picture of the realities women face in organizations. Feminist standpoint theory (Hartsock, 1981, 1983) has provided a course of inquiry for the study of women's marginalization in organizations. Like Berger's (2005) power-to relations, activism is an essential component of this feminist approach; in addition, a goal of the feminist standpoint theory is to expose injustices so they can be addressed and the marginalized can be empowered. Feminist standpoint theory has framed the researcher's analysis of and her attention to the ways in which gender shapes female PR managers experiences of power. Thus, the research question that guided this research was: How do female PR managers in highereducation institutions perceive that they gain influence in their jobs? Studying how these women gain power will allow practitioners and researchers to develop deeper understandings of the complex factors that keep female public relations managers' in higher-education settings from gaining influence.

For the study, the researcher conducted one face-to-face and 11 phone, semistructured interviews with senior-level, female PR practitioners who work in highereducation institutions. The researcher explored how these women perceive that they gain and exert power as communication managers. Obstacles and opportunities 
communicators confronted as they assumed and carried out the role of communication managers were also of interest to this study. The researcher analyzed interview data using thematic analysis (Lindlof and Taylor, 2002).

The following section presents the literature review. The review examines female practitioners' presence in management, the structuralist perspective of gender in organizations, feminist standpoint theory, power and influence in the context of public relations, Berger's sources of power, additional sources of power, power that comes from practitioners' roles within organizations and, finally, female PR practitioners' ascent into management. 


\section{Literature Review}

\section{Female practitioners' presence in management}

Women comprise half of the U.S. workforce, yet a limit to the upward mobility of women or a "glass ceiling," remains. Women workers are, "on tap, but not on top" (Stivers, 2002).

Women have been paid less, done a disproportionate share of the routine work, struggled with the question of how to accommodate themselves to organizational practices defined by men, brooded over how to turn aside men's advances without losing their jobs, and fought to balance work demands with what was expected of them — what they expected of themselves — on the domestic front. (Stivers, 2002, p. 37).

Research has addressed some of the challenges women face in the workplace, such as discrimination and sexual harassment, as well as the difficulties of maintaining a worklife balance (Hoffman \& Cowan, 2010; Buzzanell, Meisenbach, Remke, Liu, Bowers, \& Conn, 2005; Serini, Toth, Wright, \& Emig, 1998). Women numerically dominate the PR industry, yet their struggles to balance work and family demands while climbing the corporate ladder mirror those of women in male-dominated industries, such as engineering and business. 
Understanding gender as more than mere physical sex differences is necessary to further explore how gender shapes individuals' workplace experiences. "More than a variable, gender is a system of meanings that sculpts individuals' standpoints by positioning most males and females in disparate material, social and symbolic circumstances," (Wood, 1995, p. 110). Rakow (1989) defined gender as, "a meaning system that is fundamental to how the worlds we live in are ordered and characterized," (p. 289). Further, within the meaning system, traits and behaviors are either masculine or feminine. Traits and behaviors such as cooperation and community are associated with feminism and traits and behavior such as individualism, rationality and competition are associated with masculinity (Rakow, 1989; Aldoory et al., 2008).

Previous literature (O’Neil, 2003; L. A. Grunig, Toth, \& Hon, 2001; Hon, 1995; Hon, L. A. Grunig, \& Dozier, 1992; Serini, Toth, Wright, \& Emig, 1998; Tam, Dozier, Lauzen, \& Real, 1995; Toth, Serini, Wright, \& Emig, 1998) addressed the gendered nature of PR and how organizational structures reinforce men's authority and exclude female practitioners from management. O’Neil (2003) found female communicators reported to organizational leaders less often than male practitioners, which suggests women have less access to decision-makers. This finding is troubling because previous research has posited, for public relations practitioners' influence and professional status within organizations to improve, involvement in decision-making teams is essential (Reber \& Berger, 2006). Without management positions and with limited access to 
decision makers, female practitioners face pressures to adopt masculine behaviors so they will be seen as like-minded by organizational leaders and gain more access to executives (O’Neil, 2003).

Research on gender and public relations had examined practitioners in a variety of settings, yet research evaluating the experiences of female communicators in highereducation institutions remains limited. Weaver-Lariscy, Cameron and Sweep (1994) examined gender differences among PR officers in colleges and universities using a survey of nearly 400 PR practitioners. The researchers found that female communicators were more likely to serve as the "consciences of the organization," and as such, more often participated in discussions about social responsibility. Male communicators, on the other hand, were more likely to serve as "dominant insiders," and considered themselves able to argue with others in decision-making circles about policies that affected their institutions.

For women who work in higher education administration, career paths to management positions still follow traditional models that make it easier for men to advance. Men receive more assistance moving into administration while women's advancement is slowed (White, Riordan, Ozkanli \& Neale, 2010). Ballenger (2010) studied the exclusion of women in higher education leadership and found women took slower career paths, for which they faulted prescribed advancement through formal positions in the institutional hierarchy such as assistant professor, associate professor, assistant dean, dean, provost, etc. Men's advancement did not necessarily follow prescribed advancements through formal positions. In addition, a lack of mentors and 
"good old boy networks," groups of men who look out for each other and themselves, contributed to women's exclusion in higher-education administration. "Men tended to mentor other men. They went to lunch together, played golf together, and watched football together, often excluding women. During many of these events, the men made decisions about people and positions without obtaining input from women," (Ballenger, 2010, p. 16).

As in other fields, higher-education administration provides challenges for women who wish to ascend to their institutions' highest-ranking management positions. This study helps fill the gap in research by addressing how female communicators in academic institutions become managers and how the male-dominated environment contributes to their power.

\section{Structuralist Perspective of Gender, Power and Organizations}

Kanter's $(1976,1977)$ work on men and women in organizations established the structuralist perspective, which posits that individuals' power within organizations is determined by the way in which organizational environments are structured. According to Kanter, power is established by the entire organizational environment, or system, which consists of individuals' formal positions in the organizational hierarchy, informal relationships among organization members and the gender ratios of groups. The difference between formal and informal, in this structuralist context, is that formal refers to conditions outside of individuals' control, while informal refers to conditions within individuals' control. Kanter (1977) asserted that studying the organizational system allows differences in power between men and women to be uncovered because 
individuals' behaviors are related to their formal positions, their informal relationships or their place as "tokens," or the only women, in the groups to which they belong. The parts of the system Kanter identifies are interconnected and difficult to dissect. Together, these systemic factors contribute to women's lack of power in organizations.

Organizational structures and stereotypes about the roles men and women should fill in the labor force repress women and are at fault for limiting the advancement of female PR practitioners (Hon et al., 1992). Female public relations practitioners might be marginalized within the formal structures of an organization. This, in turn, limits their ability to make connections to those in higher positions of authority with whom they could network to bolster their influence and advance up the career ladder. Even women who become PR managers face additional struggles, as researchers (Berger, 2005; O'Neil, 2003) have suggested that access to leaders and membership in organizations' decision-making teams does not automatically guarantee PR practitioners will influence an organization's direction. Exclusion from informal networks for female PR managers in higher-education institutions could look like female practitioners' absence from donor or alumni events after work or their omission from golf and other sports games among colleagues or with department heads and deans. These informal activities increase relationships among co-workers, and when women are absent from these activities, they miss the opportunity to network with their peers and thereby limit their abilities to gain influence. Finally, the low number of women in management and in certain departments has given them "token" status. For a female PR manager, this might mean that she gains membership in her organization's decision-making team, but she finds herself the only female manager among a group dominated by male executives. Working in male- 
dominated environments brings additional challenges to female communicators, especially if masculine behaviors and ideals are equated with competence. For PR practitioners to have "seats at the table," they must show managers that they are competent, valuable and trustworthy (Bowen, 2003).

Interrelated formal and informal power structures as well as women's underrepresentation in work groups have kept women on the sidelines of organizational play. Gendered organizational structures may be a contributing factor to why women in general and female PR practitioners in particular fail to ascend organizational ranks into management positions.

\section{Feminist Standpoint Theory}

The structuralist perspective helps contextualize how factors within organizational systems contribute to female practitioners' powerlessness in organizations. To understand female practitioners' perceptions of what hinders their power struggles, feminist standpoint theory has informed this study. In her early works on feminism, Hartsock (1981) situated feminism as a mode of analysis through which to approach life and politics and asserted that feminism's power as a method comes from its ability to connect life with the societal institutions that shape life (Heckman, 1997). Hartsock (1983) later introduced feminist standpoint theory in her book, Money, Sex, and Power, and says the theory, "expresses female experience at a particular time and place, located within a particular set of social relations" (p. 303).

Hartsock's original formulation of feminist standpoint theory situated knowledge in the material lives of individuals. For feminist standpoint theorists, the social groups 
within which individuals are situated powerfully shape their experiences and knowledge as well as how they understand and communicate with themselves, others and the world, (Wood, 1997). Further, "when people speak from the opposite sides of power relations, the perspective from the lives of the less powerful can provide a more objective view than the perspective from the lives of the more powerful," (Harding, 1991, p. 269-270). In other words, feminist standpoint theorists believe that studying the experiences of individuals who are marginalized, such as women, gives a more complete understanding of power.

Research within public relations also has noted women's acknowledgements of power imbalances that go unnoticed by men. Weaver-Lariscy, Sallot and Cameron (1996) studied practitioners' perceptions of professional standards and found that female and male practitioners disagreed about whether "justice and equity for all" practitioners existed. Male practitioners reported more justice and equity than female communicators did. Female practitioners did not observe a "just and equitable" standard in the profession because, for them, it did not exist. In a survey of public relations educators and practitioners, Sallot, Cameron and Weaver-Lariscy (1998) noted significant differences between men and women's appraisals of whether men and women in PR were paid equally, with women perceiving a wider gap. In addition, female educators were more likely than men to see inequalities in the profession based on gender; a possible explanation is that women experienced the inequities while male educators did not. Because of their marginalized position, the women were able to observe injustices that went unnoticed by their male peers. 
Public relations managers typically are positioned on the fringes of management structure and have less access to decision-makers. What is more, women working in higher education also are marginalized. Female public relations managers in colleges and universities face distinct challenges because of their gender and their jobs and have standpoints deserving of study. Although the women in this study are not necessarily marginalized to the same extremes as other groups, such as entry-level female communicators who completely are absent from organizations' decision-making groups, female managers' disadvantaged positions on the sidelines of dominant coalitions enables them to offer insights to how power is accumulated among leaders in higher-education administration.

Feminist standpoint theories not only seek to develop understandings of differing standpoints. Another essential component of feminist standpoint theory is its emphasis on political activism. As such, standpoints help create important personal and social change (Dougherty, 1999). Studying the experiences of female communication managers in colleges and universities will help expose the struggles the women face. Exposing these struggles is the first step in reforming environments so that women have more power.

Feminist standpoint theorists have asserted that women's experiences can vary and that women do not necessarily have the same standpoint; however, some commonalities may exist due to group membership (Buzzanell, 1992; Heckman, 1997). Despite varying standpoints, women can come together to work toward shared goals, such as more participation in organizations' decision-making teams (Buzzanell, 1992; Heckman, 1997). Heckman (1997) argued for a revised understanding of feminist 
standpoint theory in which the feminist standpoint is positioned as "situated and engaged knowledge, as a place from which feminists can articulate a counterhegemonic discourse and argue for a less repressive society,” (p. 363).

Taking a feminist standpoint approach to this analysis seeks to give voices to female PR managers who may have difficulty gaining access to management or becoming managers. Further, feminist standpoint theory offers a framework to explore the varied experiences of women in PR and expose ways in which changes are needed so women can have more power. Pompper (2007) used standpoint theory and uncovered that Latina practitioners felt their gender and ethnicity marginalized them, and they did not feel valued or trusted to do the same kind of job as their White male peers. Further, the women felt they had to suppress their bicultural identities and behave in ways that were "normal" to their Anglo men co-workers.

By studying female PR practitioners' standpoints, the researcher hoped to gain a deeper understanding of how the women experience power in their jobs. Exposing the women's struggles gaining power will allow researchers and practitioners to acknowledge, respond to and reform the practices that continue to keep female public relations managers trapped beneath glass ceilings in higher-education administration.

\section{Power and Influence in PR}

Previous literature using feminist standpoint theory to address how gender affects female PR practitioners' marginalization in management positions remains limited; however, research examining gender, influence and power in PR practice abounds. Carli (2001) posited that gendered ideas of how men and women leaders should behave in the 
workplace contribute to women's difficulty gaining and exerting influence. Further, Weaver-Lariscy, Cameron and Sweep (1994) asserted that, "within the structural environments of the organizations in which we work, there are strongly held perceptions of differences, derived from gender, that offer quite different interpretations of roles within the management workforce." Studying power and influence in the context of PR is of interest to many academics and professionals because of the need for practitioners to effectively convince organizational leaders of their competence as communicators and of the value of the communication strategies they develop on behalf of their organizations.

Exploring how practitioners perceive that they gain influence in their jobs will expand theorizing about what having power means to female practitioners. In addition, feminist standpoint theory will give voice to the experiences of underrepresented female communication managers, who represent a small segment of female practitioners who have ascended organizational hierarchies yet remain beneath glass ceilings.

Essential to the study of power and influence in PR is knowledge of how researchers have used the terms within research on organizational behavior. Previous literature (Mintzberg, 1983; Spicer, 1997; Kanter, 1977) on power and influence has defined the concepts within the scope of organizational structures. Kanter (1977) and Mintzberg (1983) asserted that influence occurs when individuals use power to accomplish something that serves an organizational purpose. For PR practitioners, this may mean successfully communicating leaders' messages to reporters during a crisis and garnering favorable media coverage on behalf of the organization. Power also can turn into influence through "legitimate, sanctioned organizational bases, such as those that formally come with any position or accrue through perceived expertise," (Spicer, 1997, p. 
142). In other words, practitioners might gain influence when they move to a higher-level position or become well known for their talent writing speeches for executives.

Often, opportunities for communicators to counsel management happen when organizations face issues and leaders need help handling negative media attention. Over time, public relations professionals who provide ethics counsel during crises have more opportunities to participate in strategic management. The guidance of communicators, if effective, can lead managers to trust and even seek the communicators' input in future situations. Eventually, assisting with these strategic decisions can give practitioners increased access to or inclusion in dominant coalitions (Bowen, 2007). However, as structuralist theorists have noted, earning influence can be difficult for women because they often have low positions in organizations' hierarchies and lack relationships with or access to leaders (Kanter, 1976, 1977; O’Neil, 2003).

Researchers (Berger \& Reber, 2005) have noted the subtle difference between power and influence. Power is defined as an individual's capability to get things done or to get others to do what the individual wants them to do (Barbalet, 1985; Berger \& Reber, 2005; Cobb, 1984; Greiner \& Schein, 1988; L. A. Grunig, 1992b; Hay \& Hartel, 2000; Lauzen \& Dozier, 1992). When power is defined as the capacity to get things done, influence often is defined as the exercise of power (Berger \& Reber, 2005; Hinkin \& Schriesheim, 1990; Mintzberg, 1983; Salancik, 1977). Similarly, Pfeffer (1992) described influence as the process in which power is used or realized. In a study of practitioners, PR professionals defined influence as the ability to shape organizational strategy and decisions, having access to management and having their opinions listened to (Berger and Reber, 2005). More recently, Place (2012) conducted in-depth interviews with female 
practitioners who perceived power existing as influence, relationships, knowledge and information, access, credibility and empowerment. These descriptions of power refer to that which enabled the women to have power. For example, relationships are not necessarily power, rather, the possession of and access to relationships affected the female practitioners' power. In addition, practitioners' perception of power as empowerment "reflects an evolution of the definition of power in public relations and suggests that power is perceived as something not given, but something shared by individuals. Combined, evidence refutes traditional notions of power as simply a commodity that can be given and that some individuals possess and some do not," (Place 2012, p. 446).

Although often defined separately, power and influence have also been used as synonyms in more recent literature (Berger and Reber, 2006; Aldoory et al., 2008). Thus, this research also will use the terms interchangeably. Because of the exploratory nature of this study, a specific definition of power/influence does not guide this research. Rather, the formulations of power-relations proposed by Berger (2005) will inform this research.

Berger's types of power. Berger (2005) placed power in the context of PR using three types of relations: power over, power with and power to. Berger (2005) asserted that power-over, power-with and power-to relations exist in a constant state of shared change. In power-over relations, control, instrumentalism and self-interest characterize the decision-making process. In a power-over system, practitioners do as they are instructed to do by those in authority (Aldoory et al., 2008). Conversely, power-with relations emphasize dialogue, inclusion, negotiation and shared power in decision- 
making (Berger, 2005). Communicators in a power-with system serve as organizational advocates and help build relationships between the organization and its audiences (Aldoory et al., 2008).

Inside dominant coalitions, a tension exists between power-over and power-with relations because of the gendered nature of each style. Power-over relations align with masculine traits of independence and power-with relations embody feminine ideals of community (Dougherty, 1999). Finally, power-to relations refer to types of resistance practitioners might use to counteract the gendered dialectic between power-with and power-over relations. Practitioners of power-to relations are activists who work to improve their power in advising dominant coalitions (Berger, 2005). As activists, PR professionals attempt to influence managements' decisions by sharing audiences' attitudes toward the organization with leaders during the decision-making process (Grunig, 2006). For public relations practitioners to increase their power, they must employ activist practices that work on behalf of the whole organization and oppose authoritarian systems of dominance (Place, 2012).

Berger (2005) positioned power-to relations as the type of influence practitioners should employ. This type of power aligns with feminist empowerment-based formulations of power and departs from masculine notions of power-over, or power as domination. In a power-to system, practitioners are political actors and, as such, "they must use political intelligence, resources, and willpower to push back on the forces, processes, practices, and structural arrangements that otherwise constrain their abilities to help organizations do the right thing in a complex world," (Berger \& Reber, 2006, p. 69). 
In power-to relations, communicators challenge dominant forces and empower those who may have been silenced by power-over systems.

Additional sources of power. For PR practitioners to increase their influence, they must understand the sources of power within organizations. In an influential study of power in organizations, French and Raven (1960) proposed five bases of social power: authoritative or legitimate power, coercive power, expert power, referent power and reward power. Authoritative or legitimate power refers to an individual's assigned position or title within the organization's structure. Those working as executives have higher authoritative power than those in entry-level positions. Coercive power comes from the ability to impose punishments. Conversely, reward power comes from the ability to give rewards and resources. Often times, coercive power and reward power come from managers who can dole rewards and punishments to their direct reports. In addition, certain groups within organizations can have reward or coercive power. The budget committee can give funding to certain departments while taking monies away from other departments. Those with specialized knowledge or skills have expert power. This power, arguably, is what PR practitioners most often possess because of their technical skills as writers and communicators. Referent power refers to an individual's personal characteristics, such as charisma and attractiveness. As persuasive communicators, PR professionals likely have referent power as well. Information power, the authority that comes from access to or control over important information, was added to French and Raven's (1960) original set of five power sources by Bachrach and Lawler 
(1980). PR practitioners have information power when they are charged as the organizations' spokespersons, especially during crises.

\section{Power as a function of practitioners' assigned and perceived roles. PR} practitioners are likely to possess expert power because of their technical skills, but authoritative power typically only resides with PR managers who have higher positions in the organizational structure. Depending on the organization, PR managers have varying degrees of involvement in strategic planning and advising the dominant coalitions, (Dozier et al., 1995). This is troubling because, without consistent access to coalition members, communicators' authoritative and information power can wane.

Previous research (Dozier \& Grunig, 1992; Dozier et al., 1995; Grunig, 1992) has found that PR is best when those who practice it are members of dominant coalitions or directly report to one of their members or, in other words, when practitioners have authoritative power. Having authoritative power makes communicators more likely to have consistent access to coalition members. Conversely, when communicators do not have authoritative power, they may gain access to coalition members using other types of power, such as expert or referent power.

Using two separate studies, Berger and Reber (2005) completed semi-structured interviews with $162 \mathrm{PR}$ practitioners and found practitioners had the most influence during crises and when developing communication messages or plans. In other words, practitioners had expert power because coalition members sought the practitioners for their abilities to create communication products, such as news releases. Communicators who were interviewed said they had the least influence during strategic decision-making 
and during interactions with organizational executives. Practitioners lamented that coalition members perceived them as technicians rather than managers, which suggests the professionals lack authoritative power. When organizational leaders need a communication product, PR practitioners have power; however, according to the practitioners who were interviewed, their technical skills alone are not sufficient to gain them positions as strategic counsel (Berger and Reber, 2005).

Women may be less likely to be included in strategic decision-making because they are more likely to have formal roles as communication technicians than they are to have managerial positions (Toth et al., 1988). Technicians help produce content or perform duties delegated to them, duties that can include writing press releases, planning events or making media contacts (Berger, 2005). Technicians have low authoritative power, which might contribute to their absence at organizations' decision-making tables. Dozier and Gottesman (1982) asserted that PR managers, who more often are men, out earn technicians, have higher education levels and are more likely to participate in organizational decision making. Weaver-Lariscy, Cameron and Sweep (1994) found women practitioners were significantly more likely than their male colleagues to classify themselves as communication-technicians rather than communication managers.

Current research has failed to fully uncover why few female practitioners transition from the technician role to manager role and what challenges face women who become managers. Although managers have more influence than technicians, having a position as PR manager does not guarantee influence (Aldoory et al., 2008). Even practitioners' inclusion in dominant coalitions does not automatically guarantee leaders will heed the communicators' advice (Berger, 2005; O'Neil, 2003). Gaining influence as 
communicators may be difficult for women because they practice a gendered, female profession in male-dominated environments. Female communicators have lower positions in organizational hierarchies, which stymie their advancement into leadership when combined with limited access to coalition members and absence from seats at the decision-making table. In addition, women's exclusion from "good old boy" networks keeps them alienated from informal networks in the workplace that, for men, help establish mentoring relationships that aid in career advancement. Together, many factors work against female practitioners' advancement and hinder their influence as communicators.

\section{Understanding Female PR Practitioners' Ascent to Management}

The present study sought to explore how female public practitioners gain power and thereby ascend to management positions in higher-education institutions. In addition, the researcher sought to understand the standpoints of female PR managers. Feminist standpoint theory ascribes value to understanding women who are marginalized, such as female PR managers who, because of their gender, are the minority among managers within their field and within their higher-education workplaces. This study strove to understand more clearly the types of influence that have helped female PR managers obtain their current positions. In order to explore the factors that contributed to female 
practitioners' influence as communication managers, the researcher proposed the following question:

RQ: How do female PR managers in higher-education institutions perceive that they gain influence in their jobs? 


\section{Method}

To answer the research question of this study, the researcher conducted semistructured, in-depth interviews with senior-level female PR practitioners who work in higher-education institutions. Interviews help researchers explore participants' perspectives of communication events or processes (Lindlof \& Taylor, 2002). In addition, interviews allow researchers to probe deeply into participants' experiences by asking questions about data that cannot otherwise be observed (Keyton, 2006).

\section{Inclusion Criteria}

To determine eligibility of participants for the study, the researcher asked each potential participant screening questions, including their title, their place within the reporting structure of their institution, the number of years they have worked in the public relations industry and how often they have access to their organization's top leaders (chancellors, presidents, etc.). This helped the researcher guarantee that the women had sufficient experience with dominant coalition members to discuss their interactions with group members. When possible, the researcher verified the women's self-reports by checking their organizations' staff listings and/or by calling the college or university for which they work. Once the researcher verified the participants' self-reports and gained their consent to participate in the research, she scheduled interviews with participants that each lasted about an hour.

To participate in the study, women had to meet at least three of the four following criteria: currently be working as PR managers, have more than 10 years of experience 
working in the communication industry, be members of senior leadership or directly report to members of their institutions' senior leadership teams, provide in-house PR counsel for the college or university for which they work. Requiring that women had worked in the industry for more than a decade helped warrant that they had sufficient experiences about which they could comment. In addition, the criterion that women must be members of their organizations' dominant coalitions or directly report to a coalition member also ensured that the participants could adequately offer insights into dominant coalition communication and power exchanges. Women who worked for PR agencies were not of interest to this particular study because of their focus on multiple external clients.

Because of their organizational rank and years of experience, the women in this study represent those who have ascended the ranks of their organizations' hierarchies and, in doing so, have made it farther than many of their female peers. They represent a relatively select and highly successful group of communicators, yet the women report that they still lack influence among institutional leaders in certain situations. Because of their marginalized place in organizations, they are uniquely positioned to provide insight into power and gendered relations in dominant coalitions.

\section{Sampling Procedure}

The researcher used purposive and network sampling to recruit participants. Using the researcher's professional networks, she identified key informants who met the qualifications to be included in the study or who could recommend others who would meet the criteria. The researcher followed up with the suggested participants via email 
and/or phone calls to confirm they met the inclusion criteria. The purposive and network sampling did not yield sufficient participants, so the researcher also used snowball sampling to gain more participants. The researcher obtained oral consent from participants at the beginning of the interviews, which allowed her to avoid additional written links connecting participants to the data. The researcher also obtained the participants' oral consent before beginning digital recordings of the interviews. No compensation was offered to the participants.

Because of geographic constraints, 11 of the interviews were conducted via phone and one interview was conducted face-to-face. The researcher conducted the phone interviews at times convenient to the participants, and she conducted one face-to-face interview at a location of the participant's choosing. On average, the interviews lasted between 45 minutes and an hour, as many of the women used their lunch hours to talk to the researcher.

\section{Interview Procedure}

The researcher used semi-structured interviews and followed a predetermined interview guide, as is typical with semi-structured methodology, to ask interviewees a series of questions about their experiences with power and their career paths. Using a guide to conduct the interview allowed the researcher to stay on task while still providing the flexibility to pursue other trains of thought suggested by the participants. The appendix includes the interview guide that lists specific questions the researcher asked the participants. 
In addition, the interview guide used a "funnel-approach," in which the beginning questions were broad and impersonal and the questions gradually transitioned into more pointed, sensitive questions (Lindlof, 1995). In order to generate more detailed descriptions, the researcher asked probing questions, such as "How did that make you feel?" and "Can you explain that situation in more detail?"

The researcher obtained participants' consent to audiotape 11 of the 12 interviews, which were later transcribed verbatim. Including nonverbal fillers, such as "umm," allowed the researcher to capture even the subtleties of the participants' responses and ensured that the transcription captured the essence of the responses. After the transcriptions were completed, the researcher verified their accuracy by reading the transcripts as she listened to the recordings. When the transcripts did not match the recordings, the researcher corrected the transcripts.

Lindlof and Taylor (2002) caution that sample size is difficult to predetermine in qualitative studies; therefore, researchers should continue sampling until no new information is added. After 12 interviews, the researcher saw themes emerging in the data, and the interviews did not continue to reveal new information or challenge previous data collected, which indicated the researcher had reached a critical threshold of interpretation (Lindlof \& Taylor, 2002, p. 129).

\section{Data Analysis Procedure}

Because of the exploratory nature of the study, the researcher used thematic analysis to interpret the data collected from the interviews. Thematic analysis, also 
known as thematic interpretation (Owen, 1984), is grounded in how participants perceive communication episodes. Further, themes are conceptualizations of interactions, relationships, or events. In textual data, themes are identified based on recurrence, repetition and forcefulness. These three criteria helped the researcher identify the salient issues and the extent of the issues' salience for the women she interviewed. Recurrence happens when the same thread of meaning is present more than once in the data. The wording need not be exactly the same; rather, the same meaning is what matters most. Conversely, repetition refers to use of the exact same words, phrases or sentences (Keyton, 2006, p. 295-296). Forcefulness occurs when the data indicate, "vocal inflection, volume, or dramatic pause which serve to stress and subordinate some utterances from other[s]" (Owen, 1984, p. 275-276).

Lindlof (1995) suggested three steps of thematic analysis: reduction, explanation and theory. Reduction refers to sorting data according to potential themes and conceptualizing possible labels for the themes. Explanation comes from combining participants' explanations with the researcher's experiences and knowledge. Finally, the researcher interprets the themes and/or applies the themes to a theory (Lindlof, 1995). Using these three steps allowed for an inductive process through which theory could organically arise from the data.

To make sure the researcher's interpretations aligned with the participants' experiences, the researcher used member validation during the interviews. This process involved the researcher sharing her interpretations of the data with the participants, and asking the interviewees to verify that the researcher's analysis was accurate (Keyton, 
2006). In addition, the researcher used follow-up emails to participants to clarify her analysis and to ask for further elaboration when more information was needed after initial analysis.

The biggest challenge to the researcher was scheduling interviews with the participants. Because of the nature of their jobs, the women's schedules were in constant flux, and the participants had difficulties committing to interview times far in advance. As a result, the researcher remained flexible with scheduling interviews so that she could accommodate the participants' work demands.

\section{The PR Managers}

Although the women all held management positions, they had a variety of titles, ranging from director of media relations to vice chancellor of marketing and strategic communications. In addition, the women had an array of professional experiences, such as careers in journalism, government relations and small-business ownership, before entering the field of higher education. On average, the women had more than 20 years of experience in the larger communication industry (practicing PR or journalism) and about half had more than 10 years practicing PR in the higher-education setting. The majority of the women worked at colleges and universities in the Midwest, although four participants worked at universities in southern states and one woman worked at an institution on the west coast. Most of the women worked at public research universities, although a few women worked at private institutions and one worked at a community college. The women ranged in age from 34 to 62, and all but two were married. Eleven of the 12 participants had children that ranged in age from infancy to adulthood, although most of the children were in their late teens or early 20 s. In order to represent the 
participants' backgrounds, the researcher has provided a brief biographical profile of each participant. The women's names were changed to maintain their confidentiality.

Angela. Angela has worked at the same Midwestern, public university for more than 20 years. She's in her late forties, is married and has two children who are 18 and 20.

Anita. After spending two decades advancing through the newsroom ranks at a metropolitan daily, Anita became accepted the senior-most communication position at a Midwestern, urban, public university. She is 48 , married and has three children who are in their late teens and early 20 s.

Holly. Holly has worked the same mid-sized public university in the Midwest for more than 20 years. She has been married for nearly the same amount of time and has two children, one in high school and the other in college.

Janet. Janet joined the staff at a small, private university almost a year ago after spending a decade running her own public relations and marketing business out of her home. She is in her late thirties, is married and has three children who are 13,11 and six.

Kim. Kim directs media and internal relations at a large AAU university in the Southeast. During more than 20 years in the communication industry, she has worked as a reporter and now has been practicing PR in the higher-education setting for nearly a decade. Now in her late forties, Karen is a single mother to two children in their early twenties.

Linda. Linda is 55, married and has two children in their twenties. She works for a public AAU university in the Southeast and has more than 30 years of professional experience. 
Lauren. Lauren worked as a newspaper reporter and editor for more than a decade and has spent the past 15 years in PR at two AAU institutions on the West Coast. She is in her late forties and, after time as a single mother, she recently remarried and has two children who are 20 and 17.

Marilyn. Sixty-year-old Marilyn has spent the last 10 years in PR but worked in television news for 25 years prior. She is the senior communication administrator at a large public university in the Southeast. She is married and has no children.

Melanie. The youngest of the participants, Melanie is 34, married and has a baby. She manages communication efforts at a large, community college system in an urban, midwestern area. She has worked at the college for more than six years.

Nora. After more than a decade practicing healthcare PR, Nora joined her large Southern AAU research university more than two decades ago. She's advanced through the communication ranks at the university and now is the senior-most communication administrator. Nora is 57 , unmarried and has no children.

Sharon. Sharon has worked in PR for almost 40 years and has been married for nearly the same amount of time; she has an adult son. Now in her sixties, Sharon directs communication for a school at a large Midwestern public university and also has a faculty appointment.

Vera. Vera has held a variety of positions throughout her more than 20 years at the same small, private university in the Midwest and now co-directs the institution's marketing and communication efforts. She is 48 , married and has three children, who are 24, 21 and 16. 


\section{Results}

The researcher conducted 11 phone interviews and one face-to-face interview with female public relations managers working in colleges and universities. The interviews gave the women an opportunity share their experiences practicing PR in the nuanced higher-education setting. Women shared a passion for public relations and for working in higher education. In particular, emphasis was given to collecting descriptions from participants about the relationships they had with their internal constituents, coworkers, administrators and campus colleagues. However, many women also voluntarily shared information about their personal lives, particularly with regard to their families and spouses.

The participants' responses have been thematically organized. Each thematic section includes the quotes that most exemplified participants' responses. First, the women's descriptions of power and influence will be discussed, followed by their perceptions about how they gain influence in their institution. In addition, the following section will address the women's discussion of work-life balance as well as their thoughts about working in higher education. Finally, the section will conclude with the women's recommendations for the next generation of female PR managers in higher-education institutions.

\section{Power and influence: Subtle differences shaped by connotations}

In order to place the entirety of participants' responses within the necessary context, we must first begin with a discussion of how the female public relations managers viewed power and influence. 
Participants overwhelmingly said that 'power' had a negative connotation and was related to individuals wielding power over others. Holly explained it this way, "Influence to me is certainly a more positive word and can be used to bring people along whereas the word power may imply that, whether you like it or not, this is the way it's going to be." The majority of the participants said something similar when asked about what influence and power meant to them. Perhaps, the women's negative association with the word 'power' is related to women's discomfort with labeling themselves as 'powerful.' The participants don't view themselves as powerful because they construct power as overpowering and authoritative, which doesn't seem to align with their communication or leadership styles. In addition, women may not like the word 'power' because of societies' and the media's perpetuation that women are not supposed to be powerful. Men are supposed to be powerful, strong and authoritative while women are supposed to be sexy, submissive and sensitive, according to media and societal messages. Perhaps the women have been acculturated to think that, even if they are successful, they are not powerful. To label themselves as powerful would be boastful and could cause others to label them with the B-word, as careerist women sometimes are labeled.

Nearly all participants disassociated with the word 'power' and much preferred using 'influence' to label their own successes or the achievements of those whom they admired. Kim explained:

I am more drawn to the word 'influence' than I am 'power.' Power sounds like it's more of a...like it's more attached to a person's personal ego, I think. I think 'influence' is a little bit more about—you earn respect by being a hard 
worker. Power is more, you know... 'I'm the 'fat cat,' who is sitting in the big office.” And that doesn't define me at all, I don't think.

In her response, Kim distances herself from power. To her and other participants, 'power' is authoritative, self-important, unfeeling and related to high positions within organizations. Influence, on the other hand, is associated with working hard and proving oneself, thereby earning the respect of others.

Although the majority of the women viewed 'power' negatively and did not use the word to describe themselves, the data do not support simplifying 'power' as bad and 'influence' as good. Rather, the two words remain complex and interrelated concepts with nuanced and gendered distinctions. Angela described the interrelatedness of the two terms:

Angela: I think of influence as having the respect of other people and being able to command attention in certain situations.

Angela: How would you define power?

Angela: Power is your ability to be able to move someone to change, I guess. Researcher: Do you think power and influence are related, and if so, how? Angela: I think they are definitely related because it feels that the more power that you wield, the more influence that you have. I think that the power tends to go along with the hierarchy of structure at the university, and so maybe, the higher up you are the more power you have and the more power you have the more influence that you have.

The previous response also suggests Angela associates power with organizational structure, which many participants mentioned. Lauren noted power and its place within 
individuals performing specific university functions.

People with power are the ones that can control the budget and control the final decisions. Then influence you can have just simply because you have the knowledge that no else has, and they [administrators] need it. So if you are the only communications person in the room, and you are the only person that really has a deep understanding of how media work, or how something is going to play, or you are the only one who can actually write something that is coherent, or you are the only person who can listen when 15 people are talking about and then put it into a document so that is understandable, then you have influence.

Lauren's response indicates she perceives that influence is earned and comes from assisting in times of need, from providing counsel or expertise that others do not possess. In summary, participants prefer to use 'influence' rather than 'power' when talking about themselves and their work. Perhaps, the women dislike and disassociate from the word 'power' because it has a more authoritative, masculine connotation, whereas they associate 'influence' with something earned through hard work and proven skill. They don't necessarily distance themselves from power because they are afraid of making the tough decisions; rather, the participants seemed to want to have more of a voice in decision-making. To label themselves as powerful or to behave in powerful ways would be to push themselves outside of what society expects of them as women. By distancing themselves from power, the women are acting according to their assumptions that women should be nice and get along with everyone, which contrasts sharply with their idea of power. The women's understandings of 'power' relate to Berger's (2005) conceptualization of power-over relations in which power is related to getting others to 
do what one wants them to do, whereas their understandings of 'influence' more closely align with Berger's power-to relations and feminist empowerment-based definitions of power. In a power-to relations, power is referred to as the capacity to do something, such as provide expertise or counsel.

\section{What gives individuals influence?}

Several themes emerged about what gives PR managers influence in the highereducation setting. These themes include collaborative relationships, issues/crisis management, and the personality traits of honesty, decisiveness and tenacity.

Collaborative relationships. Nearly all of the participants mentioned that possessing good working relationships with members of the media, colleagues and university administrators was important for gaining influence or being influential. In particular, collaboration also emerged as a key feature of their relationships and their leadership styles. To the female practitioners, collaboration facilitates relationship development and thereby helps individuals gain influence. Some women were hesitant to admit collaboration was an inherently female leadership quality, although many recognized collaboration as something at which women excel. As Anita said:

What women do bring to the table is they assist more, it's not always about winning — it's certainly not always about winning as a human being, as an individual - it's more about, 'how can we get people around the table to figure out a solution to this? What ideas do you have? Let's talk about this.' Umm, you still have to be able to make decisions, so you still have to, you know, be ready to call the shots as a leader when the time comes, and I don't see any hesitation in women to do that. 
Anita's explanation refers to women's ability to collaborate by asking for input from others while problem solving to make decisions. For her, collaboration and decisiveness are not necessarily mutually exclusive.

Holly noted the ability to bring people together toward a shared goal through communication:

Well, [people who have influence] are really, really good listeners and they have the ability to work within a diverse group of opinions, especially some opinions that are really diametrically opposed to maybe what ultimately the goal is. But yet they have the ability to make that rapport together, eventually, to come to a consensus. I call it communication skills I think are critical, and certainly being able to have a vision and have others around you that understand that vision. Holly's comment suggests women are able to use their skills at collaboration to bring opposing viewpoints together, which helps during conflict resolution.

Janet's comment echoes Holly's sentiment and places collaboration in the context of higher education.

Especially with working in higher ed, you know, we've got a lot of departments. We've got a lot of different entities that want to help and that work in different ways, and so, you know, part of what I try to do is make sure that they're all heard and that we listen... figure out, 'okay, yeah, that makes sense,' or if we disagree, then trying to kind of show them, 'well, let's think about it this way,' or, 'let's try to do it this way.' 
In a way, Janet praises PR managers for doing what, ideally, they're supposed to do: listen, synthesize information, and communicate the information in ways that others can understand.

Several women noted responsiveness, accessibility and dependability as other personal attributes that facilitate good working relationships. Melanie's response touches on all three attributes and was characteristic of many participants' comments:

Obviously, I consider a lot of my colleagues to be a lot of my internal clients because they are the subject matter experts on the projects and the initiatives that I'm trying to create stories around. So just developing good working relationships with them where they know that they can depend on me to do stuff is important. Relationships with others allow female practitioners to bolster themselves and their work and to develop track records of success. One major component of the women's track records is their ability to handle negative issues facing their institution appropriately so that their institutions' reputation can be upheld.

Issues/crisis management. As Vera noted, "Crisis communication is probably the single most important thing that a PR individual representative can do for an institution if they do it well." Many women echoed this sentiment through stories they shared of their own experiences handling issues that could be potentially negative for their university or college. Kim said, "You know, I carry a lot of influence in handling emergencies because our department is so dependent on how quickly we can push out information and how quickly we can respond to the media." Many women shared concrete examples of crises they had managed when the researcher asked them to, "Tell 
me about a time when you felt particularly influential or powerful." Overwhelmingly, the women shared stories about managing media coverage during issues that had the potential to damage their institutions' reputations.

In particular, Angela said she felt influential when she handled reporters after members of the national media descended on her university's campus after a former student allegedly plotted to set off a bomb in New York. Anita shared how she coordinated external and internal communication for her university after a student was murdered during a home invasion near campus. She noted that her efforts and communicating timely information to faculty and staff helped her and her team gain influence with administrators and others across campus:

Anita: I was able to do some things with [the media] that I don't think... they're not brain surgery... but they're things that hadn't been done prior, with the prior, um, media relations team that worked for the university. And they were really simple things like interfacing with the media so the family wouldn't, you know, be called 29 times and asked the same questions about the incident. So, we basically fielded the media requests and then connected the family and/or other university people to the media in a way that respected this horrible time that the family was going through.

Researcher: Sure.

Anita: Then we created a communications piece that went out to faculty and staff and students on social media and email and later in some of our other media to keep people up-to-date about the crisis to make sure people 
knew what was being done and how the campus was responding and how they could help if they wanted to or how they could get help if they needed help. So...so there are things like that that had never happened before on this campus that are demonstrations of us being able to show them what a public relations and what a media relations operation could mean when it's done right and respectfully and done proactively. Researcher: Sure, do you, do you think that that kind of helped establish some credibility for you among other senior leaders at the university as far as showing them what you were capable of doing?

Anita: It absolutely does. [...] And that was a really graphic demonstration, and a really difficult situation, of how we can make a difference in their lives. [...] And as a result, our um requests for partnership opportunities and projects has increased dramatically since I've been here.

Anita's response is just one example of how the women provided communication counsel to their institutions' leaders and implemented the crisis communication. In addition, Anita's story also indicates that other's noticed and respected how she handled the situation, which helped her gain credibility.

Event and campaign planning, although not necessarily negative, produce highly visible products, which often carefully are scrutinized by members internal and external to the university or college. A few women, including Melanie and Holly, shared event management as instances in which they felt influential. In 
particular, Melanie shared that she helped prepare remarks for college administrators for a high-profile event attended by President Obama. The college administrators were pleased with the outcome of the event, which, according to Melanie, made her feel influential.

When discussing crisis communications, many women noted their ability to think strategically when managing issues. In addition, they said they provided counsel to university administrators when developing messages and determining the best ways to communicate those messages to key constituents. In particular, Kim noted how her past experience managing crises helps her forecast potential negative issues, which allows her to plan ahead.

I think when I say influence, I think probably, maybe, the niche for me is, or maybe what might set me apart, is being able to look at a situation. [...] I think I am pretty good predictor of what is about to come, and that probably has been the distinguishing characteristic. [...] I have gotten through year-to-year sort of predicting crisis, kind of seeing when our reputation could be at risk.

Kim and others referred to women's advantages at using intuition and emotion in their decision-making and their ability to see the big picture. Men, they noted, seem to have a more "cut-and-dry" approach and rely more on facts than gut instincts in decision-making. Many of the participants emphasized that handling many crises over time helped them "prove" themselves and earn the respect of others, particularly administrators. It seemed that cumulative experience, rather than managing one individual event, is what helped the women develop influence. 
Although the women noted they regularly are sought out for advice in managing crises, they still feel excluded from other conversations in which they could offer counsel. Lauren explained:

I don't feel very influential though about certain kinds of practices at the university, certain kinds of policies. I don't feel influential when it comes to requesting additional resources. I don't feel influential about... I don't feel influential always in advising the president, provost or some of the senior leadership on the best course of action. I am not brought in sometimes on things when I think I could have been helpful, and I'm not consulted. [...] But I wish I had more influence, you know, to help the campus understand certain practices and certain things it does that could be detrimental in the long run. [...] I have a lot of influence as to what gets told to journalists. I have less influence about how we [the university] go about... um... managing policies.

Lauren's response suggests female practitioners, and perhaps PR managers in general, have proven themselves within the scope of media relations. However, their influence in strategic decision-making about university policies is lacking, partly because practitioners are excluded from these decision-making conversations. In addition, the practitioners often were called in after the big decisions were made and important audiences did not like the decisions. The women had to fix the messes that administrators had made. Had the PR managers been included in the initial decision-making conversations, perhaps the backlash to the decisions and negative publicity could have been avoided because the communication professionals could have advised their organizations on how to 
communicate the changes effectively or advised against policies that would be perceived negatively by key publics.

Participants overwhelmingly said successfully managing negative crises had helped them gain influence. Handling an issue well could speed up a PR managers' accumulation of influence. However, poorly managing crises could cause individuals' influence quickly to deteriorate. For the women's influence to increase, college and university administrators as well as other constituents had to be pleased with how the issues were handled by the PR managers. Although none of the participants explicitly mentioned an example of a crisis they'd handled poorly, they described the high-stakes nature of crisis communication, such that managing one issue poorly could cause the women to lose their influence and, perhaps, their jobs.

Personal characteristics: honesty, tenacity and decisiveness. In the participants' responses about what gave them influence emerged a theme of three personal characteristics: honesty, tenacity and decisiveness. They reported honest communication with leaders to whom they provided counsel, as well as tenacity in making sure information was communicated appropriately to key constituents in a timely manner. In addition, the women did not fear making decisions and expressed a need to be decisive. These women did not let fear of becoming unpopular with leaders hinder the counsel they provided. Lauren said:

One of the things that the provost told me is that she appreciated the fact that I was not a 'yes person,' that I spoke up, that I gave some advice, and my best advice, even if the people I was advising... it was not what they wanted to hear. 
Later, she added:

You need to be really strong. You need to be able to tell people what they don't want to hear. You need to be able to take these roles seriously. You are a magnet for criticism, and you need to be able to withstand that because, sometimes, you are criticized for being a messenger. So it [PR] is not a profession for anybody who is sensitive. You need to be tough—male or female—and you need to be decisive.

Lauren's comments show a resolve for making tough decisions and providing sound counsel without fear of repercussions associated with hurting the feelings of others or having their own feelings hurt. In addition, Lauren uses the gendered words, 'sensitive,' most often associated with femininity, and 'strong' and 'tough,' which are typically masculine characteristics. Lauren's word choices suggest she has bought into the societal idea that, in order to be successful, women must suppress or abandon their feminine traits and adopt more masculine behaviors in order to advance in their careers. Because she has individualized the cultural norm that successful professionals behave in masculine ways, she has lessened her ability to counteract society's ideology of how upwardly mobile female professionals should conduct themselves and reinforced the idea that masculine traits are preferred in the workplace. Melanie used the word 'strong' to describe a female administrator whom she admired at one of her community college's campuses. Interestingly, Melanie had never met the woman but had heard about her from other female colleagues who had been inspired by the leader's behavior. Melanie shared the 
plight of the administrator, who worked to make strides at a campus that had a paucity of female leaders.

She defended things and kind of pushed back against the old boys' club mentality. [...] She took a lot of flack for that, and she was thought of by other people around our district, by other men specifically, as kind of... just a little... bit negatively. I don't know if she was thought of in the 'B' word, but she was, she just had this hard-hitting kind of reputation in some circles.

Later, Melanie likened herself to the female administrator she admires:

Well, she is confident and tenacious. [...] I would consider myself to be at the level of...the strong level that I consider her to be at as far as dealing with that kind of stuff, because I would really become really annoyed by that and become really unprofessional. But based on how I see her is that she is not only confident and very well-spoken and well-educated — she has a Ph.D and she is very sharpbut she is also someone who has matured out and, at her point in her career, [...] she has figured out how to maintain that professionalism in situations where a lot of people would lose their minds, and I consider that to be an important attribute of professional strength.

Melanie's response suggests the leader had become an inspiration among younger women who worked at the university, who shared tales of the administrator's struggles and courage and aspired to be like her.

\section{Challenges to Career Success: Balancing Work and Family Obligations}

When the researcher asked the PR managers about obstacles they had to overcome during the course of their careers, nearly all of the women mentioned their 
family obligations and how having children had changed their lives. Participants did not say their children held them back, per se; rather, because they had children, the women had consciously made sacrifices and compromises in their careers so they could be more accessible to and involved with their children. For example, Anita left a successful career in a newsroom to transition to PR, which she considered to have a more consistent schedule, so she could have more time with her children. A couple of the participants had been offered promotions, and they declined because they were happy in their current positions and were relatively content with the home and work balance they enjoyed. In addition, one mentioned she preferred the technical aspects of her job, such as writing, and did not want to take on more of the managerial decisions. They worried taking on more responsibilities at work would translate into more sacrifices in their personal lives. By making conscious decisions to not advance their careers, the women chose to remain in positions in which their capacity for gaining influence was limited. As many women noted, power and influence often come to those in top administrative positions. Choosing not to advance up the career ladder may have limited the women's capacity to increase their influence at work, but it allowed them to be more involved at home.

Many women said it was difficult for them to disconnect from work when they were at home, largely because of the prevalence of technology and the nature of the PR business, such that a crisis could happen at any time, and they needed to be available to create and disseminate messages. The women desired more flexibility in their workplaces and a greater acceptance and tolerance from their institutions toward family obligations. 
Many of the women noted that they had supportive husbands; however, the single mothers expressed difficulties juggling multiple responsibilities without help from a partner.

Inability to disconnect from work. Nearly all the women had children, and nearly all of them mentioned the challenges of being working mothers and their difficulties disconnecting from work when they were at home. As Anita explained:

There are certain life-balance issues that I think affect women more than men. For instance, I am the mother of three children, and at some point in my career I made the choice to have children, and that creates some issues that I think men don't face in terms of balancing. [...] Generally we... no matter how equal men and women want to think they are, it is without question that we, women, carry at least more of a mental burden of raising children than men do.

The comment suggests Anita, even when balancing child-rearing responsibilities with a willing partner, still carried more worry about her children. Perhaps this also indicates, for women, the line between personal and work responsibilities is more blurred.

Participants acknowledged the challenge of balancing work and home lives and said it is increasingly difficult to maintain a balance in an era of 24/7 technology when PR managers are expected to be accessible at all times. Holly said:

The one thing that I have reflected a lot about, especially of late, is how drastically different things are from when I first started 22 years ago [...] social media has really changed the dynamic [...] I mean, before social media, I didn't have to check my email all the time and wonder what's going on there, what issue might have arisen in the last hour that I haven't checked my phone. 
Lauren had similar views:

Well, we really are on call 24/7, and some people have indicated, 'You are like a doctor.' 'Well, yes, or no.' A doctor is on call all the time. That will be my job. But doctors are usually on call on a rotating basis, so it is not seven days a week, every weekend, week in, week out. [...] For the first time in five years, this summer I took a vacation and did not work on my vacation.

In both of the responses, the women refer to the difficulties of trying to stay abreast of issues. When they are away from work, it is difficult for them to disconnect and feel they need to check email, Twitter, etc., to such an extent that this compulsion (arguably, need) interferes with their personal lives. Lauren shared that she had worked while she was away from the office on her honeymoon, and as the researcher interviewed her over the phone, she was driving to pick up her daughter from an after-school practice. These women are busy, yet they have tried to find ways to maximize their time when attempting to fulfill their work and personal obligations.

Personal expectations and workplace cultures. Janet mentioned that women feel like they have to apologize for having families when they try to manage both their work and home lives.

We hold ourselves to this kind of old-school standard of what a good professional... what a good employee... what all that meant. [...] And so it's not just working long hours but working smart and getting done what needs to be done and recognizing the fact that you can burn yourself out, and it's okay to understand that, yeah, you know, your family is a priority and that doesn't have to be hidden, or it should not be held against you. I think that women really need to 
seek out companies that understand that.

Janet seems to point to organizations as driving factors in creating greater balance and flexibility for working mothers.

Of the participants, all but two were married, and many women voluntarily offered information about their spouses and attributed their ability to succeed at work and at home partly to their partners. Linda explained balancing work and home responsibilities this way:

That is where you really have to have a strong communication and a strong partner in your marriage. They meet you half way. I never felt like my career had to be compromised because my husband was willing to step up to the plate. Linda has the good fortune of having a supportive partner who shares household and family responsibilities. Perhaps her viewpoint is somewhat privileged because she has a husband who actively engages in childrearing, which may have helped her concentrate more on her work obligations and take on additional assignments or stay late at the office. Conversely, single moms may not have a choice to work longer hours to finish a project if they need to leave work promptly to pick up a child afterschool every day and do not have a partner with whom they can share caregiving tasks. Nonetheless, Linda has benefitted from the help of a husband who is willing to share work at home.

Several women also noted the next generation of practitioners' desire for more work-life balance and men who want to step up more at home. Linda added:

I think we are seeing a work force coming in that really wants to keep more balance. I think that is... I think it is something that leadership needs to recognize. I think our younger force today is working to keep the balance and to do a good 
job at work but also have balance with the family, which is a good thing. [...] I'm seeing more involvement with the dads. They want to take time off when the baby is born, they are sharing, they are taking the kids to the doctor...I think more share. The roles have kind of changed a little bit.

Linda's response indicates that young professionals want more harmony between work and home obligations. In addition, her response suggests newer generations of professionals have less traditional values about the division of child-rearing responsibilities, in which the mother stays at home and is the primary caregiver for the children while the father is the primary breadwinner. She perceives that women, increasingly, want to work more, and men want to be more involved in day-to-day family responsibilities.

Lauren provided an example of a promising employee who wanted more worklife balance and recently decided to take a less prominent position so that she could concentrate more on her young children.

I just have a woman in my team I hired two years ago. I thought she really had great management, leadership potential. She is very smart, very talented. She was somebody on my team that I had been eyeing to grow and expand her scope of responsibilities, and she resigned yesterday to take a much smaller job on a team that is... on a smaller part of the university. And, so instead, she was actually overwhelmed by the magnitude of what my office does and wanted to focus on a narrower area. She's got young children, and she wanted to focus on something narrow, and she wanted to simplify, and she was looking at you know, some of 
the demands of our office, and I am not asking long hours of her, but she just felt the pressure of what she does being quite visible, and she just took a step down. Here, Lauren provided a fresh example of a young professional mother for whom the demands of practicing PR in a high-pressure, high-visibility environment were too overwhelming, so she opted to take a demotion in her career development, and perhaps, constrained her capacity to earn influence. In addition, Lauren's example shows the complexities of mentoring women. Women want guidance from their managers about how to be successful at work and at home. They want flexibility. If working mothers have male managers, the managers might perceive female employee's concerns about balancing family and work as disinterest in advancing in their careers; in turn, the women's concerns may hurt their consideration for promotions. Lower positions often mean less power and influence, according the participants. Mentoring men is perhaps easier because men simply want to know what they need to do to get ahead in their careers. Navigating women's careers can be much more complicated, and mentors to female employees should find ways to guide their success in both personal and professional spheres.

\section{Challenges of Working in Higher Education}

Several women mentioned the distinctive challenges of working in higher education, including faculty and administrators who do not understand what PR is and what PR people do. They attributed some of these misunderstandings to intelligent, welleducated colleagues who do not think they need advice of PR counsel until crises arise. In addition, faculty and administrators typically have advanced degrees, unlike many of the PR managers. As Vera said, "When you are working with an educational institution, you 
may have a skill to do a job, but if you don't have the degree behind your name they are not going to promote you because they are degree-training institution of higher learning. That is what they are all about."

Many women alluded to university politics and the occasional divide between faculty and staff/administration at their institutions. The women said the faculty versus staff mentality is something they are aware of but not something in which they participate. Anita said she does not let the divide bother her:

I worry about getting done the things that I want to get done and my ability to work with the academic side. I think on the academic side, some people would tell you that they have a lot tied up in whether they have tenure or not and how many degrees you have and so on and so forth. Umm, I'm not a snob about that (laughs). Maybe you'll need to inquire about that once I've been doing this longer.

Anita's sentiment echoes what other participants also described, a subtle difference between faculty and staff in how they define success: for faculty members, tenure matters, as does having an advanced degree. As staff persons, the women seemed to care little about faculty titles and whether individuals were assistant, associate or full professors. The women also indicated faculty did not understand how university administration, and the public relations function in particular, worked. Likewise, staff persons did not understand how the teaching and research functions worked. However, the women seemed to think they bridged between the two groups and were able to work effectively with staff and faculty members at their institutions because they understood the how both groups functioned at their institutions. 


\section{Rewards of Working in Higher Education}

When asked how practicing PR for a higher-education institution differed from practicing PR in a corporate setting, the women said working for a corporation would be more about selling products and adhering to a bottom line. Many women offered that they had self-selected to join or remain in the higher-education industry because they felt they were contributing to a cause larger than themselves: educating future generations and helping students begin, as Sharon put it, "pathways for success." Angela spoke about what kept her in the higher-education setting. She shared:

I guess I would just have to say primarily it is the people, I think it is the human element of it, and I think it is just the broader sense that, I think you feel like with everything you are doing and you are doing on a really good cause, which is the education for young people. You feel good about that. It is a little different than promoting a corporation or a corporate product or something like that.

Angela's comment echoes those of other women. They indicated they like working in higher education because it was fulfilling to promote a product (education) they believed in because of its potential to improve people's lives.

Many participants also noted they enjoyed the variety of responsibilities and deadlines they had to meet on regular basis. Lauren explained it this way:

I get bored easily, so that is why I was a journalist in the first place. That is just me. I happen to like the fact that I come to the office every day I have five meetings and have a very full schedule and three things happen before nine o'clock in the morning to divert my attention and, each day, I don't know what they are going to be. [...] I happen to like that variety, and I like the constant 
challenge, and I love what I do now, I really love my job. I have offers to do other things that I have not taken up because I happen to really like what I do. I like doing PR at the university.

Although nearly all participants mentioned their jobs could be overwhelming at times, they enjoyed their work and found it fulfilling because of the variety, the challenges and their passion for higher education.

\section{Moving forward: Advice for the next generation of female PR managers in higher- education institutions}

Many women talked about mentors who passed in and out of their lives. The women had learned from these individuals' successes and failures, and through observations of their mentors, the women had learned "what to do and what not to do." None of the mentors to whom the participants referred had been mentors in the formal sense with regular coffee dates, etc. Rather, these mentors, both male and female, had led by example. Sharon noted that she had had mentors "dip in and out" of her life, and she hoped she could do the same for younger generations of practitioners.

The researcher asked what advice the women would give to the next generation of female PR managers who wanted to work in higher education. Many of the women noted the need for young professional women to volunteer for challenging assignments. As Anita advised:

Raise your hand and take assignments that, even if you don't think someone's going to think you're good enough to do it, you might be, and the other person who raises their hand probably thinks they're good enough. (laughs). Okay, research has shown that men tend to raise their hands for the difficult 
assignments, and that's getting them bigger payoffs down the road. And women tend to wait to be asked, and are still waiting to be asked. Umm, be proactive, that's actually something I was good at. I always had a vision for my job that was bigger than what was expected of me, and I think that's generally good advice. Here, Anita urged younger professionals to volunteer for challenging projects, even if they don't feel completely confident in their abilities. Other women also advocated that women be proactive in embracing difficult assignments, which present bigger opportunities for professional development and greater opportunities to prove their skills and expertise.

Many of the participants also recommended women having more courage to ask for what they want with regard to flexibility that allows them to better balance demands at work and at home. Again, Anita shared a personal example:

My mom worked, but she didn’t work because it was a career for her. I think she just sort of fell into it out of economic need and, at some point, and, umm, if I had someone who approached their career, their work more as a career, I might have learned some of these things earlier, like it's okay to negotiate for your pay (laughs), and it's okay to ask for more, and it's okay to say, 'you know, I'm having a baby on this day, and this is how long I'm going to be gone, and let's work on how we can make that happen.' Umm, I think women have not tended to, umm, to stand up for themselves and ask for more. They tended to accept what is given to them and, umm, I figured that out at some point and began to be more assertive at that point, but I wish I had figured that out when I was 21 years old. 
As in other responses, Anita's advice urges younger generations of female practitioners to have the courage and confidence to proactively pursue career development opportunities without feeling like they are sacrificing their family lives, and vice versa. 


\section{Discussion}

This section discusses how the results contribute to understanding how female public relations managers working in higher-education institutions gain influence and how theory possibly can explain the results. In particular, this section connects the results to Berger's (2005) formulations of power and Hartsock’s (1983) Feminist Standpoint Theory.

Overwhelmingly, women preferred the term 'influence' to 'power' when describing themselves or those whom they admired. The participants also noted power had a negative, masculine and authoritarian connotation. The participants' definitions of 'power' seemed to align with Berger's (2005) formulation of 'power-over relations,' which represents a more domineering leadership style in which those with authority make decisions and pass them down to subordinates. Perhaps, some of the women's discomfort with 'power' also came from society's idea of how women should behave: as nice, caring individuals who get along with everyone. Conversely, society tells men that, "nice guys finish last," and perpetuates the idea of men as 'powerful,' 'tough' and 'strong' individuals who should be decisive and get things done. It may be that the women did not feel comfortable stepping outside of societal norms and labeling themselves as 'powerful' for fear that they would be perceived negatively. Perhaps, they accept - and thereby perpetuate - society's hidden assumptions about how individuals should enact their gender roles. 
The women said they gained 'influence' through crisis communication, facilitating and maintaining collaborative relationships and employing collaborative decision-making. These formulations of influence relate to Berger's 'power-with relations,' which emphasizes dialogue, inclusion, negotiation and shared power in decision-making. However, the participants' influence seemed to accumulate over time through displays of their expertise, particularly in managing communication during crises. Their specialized knowledge of crisis communication gives them expert power (French and Raven, 1960). Berger's third power formulation, 'power-to' relations, describes power that seeks to challenge and counteract gendered expressions of power through activism. The women's stories of their own honesty, decisiveness and tenacity indicate they are not afraid to advocate for themselves or their ideas when providing counsel to administrators. Berger's conceptualization of power-to complements feminist empowerment-based formulations of power and also seems to reflect in participants' responses.

The women gained influence through issues/crisis management, collaborative relationships and through their honesty, decisiveness and tenacity. Previous research (Berger \& Reber, 2005; Grunig, 1992; Grunig, 2006) also found that practitioners had the most influence during crises and when developing communication messages or plans. Perhaps, this is because the expertise and technical skills of communicators most often are needed when issues arise and administrators need help communicating with members of the media and other key constituents. However, some of the women still felt excluded from the table when decisions about institutional policies are being made. They felt most 
needed when they were asked to fix situations on the backend, such as responding to negative media coverage about unfavorable institutional policies or decisions. This is consistent with previous research (Berger \& Reber, 2005) that found communicators had the least influence during strategic decision-making and during interactions with organizational executives. Perhaps, if the female PR managers were included more often in institutional decision-making, they could help administrators understand the consequences of their choices and how constituents and the media will perceive their decisions. If communicators were included earlier and more frequently in decisionmaking conversations, they could suggest different policies or advise the best ways to communicate policy changes, which could help avert some crises and possibly lessen negative feedback from the media and other key audiences

The biggest challenge for the female PR managers' career paths was balancing career responsibilities and family lives. Some had made choices about their career, such as turning down promotions, so that they could have more life balance. Women noted that power came to those in administrative positions, so women who had self-selected not to advance may have limited their capacity to earn or increase their influence. Many of the women were married, and they acknowledged the help they received from their husbands; however, single mothers did not have additional help at home, which presented them with additional challenges in maintaining balance between their professional and personal lives. The women also acknowledged it was difficult for them to disconnect from work when they were at home. In particular, the practitioners noted they needed to 
be accessible and "on call" at all times, and technology is making it increasingly difficult to separate their free time from their time on the clock.

Feminist standpoint theory (Hartsock, 1983), emphasizes studying power relations from the perspectives of marginalized individuals and asserts those with the least amount of power can provide the richest descriptions. The participants had relatively more access to leaders and more responsibilities than women in entry-level PR positions and, therefore, were not the most marginalized practitioners. However, the women reported that they remained outnumbered by men in senior leadership teams at their institutions. In addition, they did not possess doctoral degrees like other members of their institutions' leadership teams, which also may lessen their influence in the academic setting. Therefore, the women still were speaking from a place of minority status, and as their descriptions of 'power' and 'influence' exemplified, the women bought into the societal ideas of how women are supposed to act. Their discourse reveals the assumption that 'power' means overpowering and being authoritative, descriptions that do not align with feminine gender roles. To them, influence was okay to possess because it was earned through hard work and expertise. Women could identify themselves as experts, but they did not want to go outside gender role expectations and be 'powerful' because they did not want to be viewed negatively, as they have been taught as women that they should get along with others so everyone will like them. .

\section{Future directions}

Based on the participants' disassociation with the word 'power,' future research should further investigate, perhaps empirically, if and to what extent women in public 
relations prefer the word 'influence' rather than 'power,' to describe themselves and those whom they admire. Furthermore, future research could examine the perceptions of women in other fields, such as engineering, healthcare or education, and study how they perceive 'power' and 'influence.' Perhaps, understandings and definitions of power and influence vary by gender, industry and workplace. In-depth qualitative studies could further examine why women practitioners reject the word 'power.' These future directions of research could help expand feminist theory about women's understandings of power and help theorists refine current definitions of 'power' and 'influence' to more accurately reflect the views of women.

Future research also should examine how technology and constant accessibility via smartphones, etc., perhaps contributes to female practitioners' difficulty separating work and home lives. The women in the study seemed to think technology made it more difficult for them to disconnect from work, and perhaps other female practitioners feel the same way. Women working in public relations face a special set of challenges because they are expected to be accessible at all times and able to respond quickly when issues arise.

Most of the women in the study had children, and of those women, only one was not married. Further research is needed to explore the additional struggles single mothers face when they try to advance their careers in public relations. Single-mom Lauren offered poignant insight into the added challenges of climbing the career ladder while independently raising children. Perhaps, future research could further examine the standpoints of single mothers who are trying to advance their careers while raising children on their own. 
The results indicate female PR practitioners working at higher-education institutions gain influence through managing crises and issues that could potentially negatively affect their institutions. Many women noted they were not always consulted during their institutions' strategic planning, and they would like to increase their input. Future research should examine why practitioners, and female practitioners in particular, are excluded from these types of administrative conversations. Understanding why practitioners are excluded from these conversations could provide clues as to how female practitioners might be able to increase their influence in strategic planning. Although female practitioners in higher education seem to have influence in managing crisis communication, more study is needed to understand why they still lack influence in institutions' policy-making and strategic-planning conversations.

\section{Limitations and Future Research}

In order to be transparent, the researcher works as an entry-level PR practitioner for a higher-education institution. The researcher did not interview anyone to whom she reports; however, her direct supervisor recommended potential participants. Additionally, one participant formerly supervised the researcher during an internship. The other participants were unknown to the researcher before the study.

The study has several limitations that could be areas for future research. This study is limited, in part, because of its methodological design. One design limitation is choosing only to talk to senior-level women practitioners. Perhaps, women who remain working in lower levels of the PR organizational structure have encountered more obstacles to career advancement and could provide better insight into gendered struggles 
in PR. Additional participants who work in the lower ranks of PR could have provided insight into gendered barriers that prevent them from becoming PR managers.

The PR managers in the study reported communicating with senior administrators on a daily basis, which gave them adequate opportunities from which to provide insight into communication going on in the senior leadership teams. According to feminist standpoint theory, those with the least power can provide a more objective view than those with more power (Harding, 1991). Perhaps, entry-level female employees or Latina or African-American practitioners would have different views of how influence and power are gained as PR practitioners in higher-education institutions. However, many of the women reported men outnumbered them in higher-education administration, so the women still were speaking from a place of minority status.

Another potential study limitation includes the small sample size and lack of diversity among participants and the universities they represent. Many of the participants came from Missouri and had similar ethnicities, ages and years of experience. Although the data are not generalizable, the data provide value because of the thick descriptions from a small, homogeneous group of women who have successfully risen to senior-level PR positions in colleges and universities. 


\section{Conclusion}

The goal of the research was to explore how female PR managers working in higher-education institutions gain influence in their jobs. The exploratory nature of the study helped illuminate female PR managers' experiences of gender and power within their college and university workplaces. Using Feminist Standpoint Theory as a frame, the research embraced the perspective that talking to those with limited or no power is how knowledge about power is gained; however, this research did not address race or class, which further could contribute to individuals' experiences and understandings of power.

The female PR practitioners shied away from the word 'power' but seemed to resonate with the word 'influence' because, to them, it has a more positive connation is earned through hard work and expertise. Power, on the other hand, is given to individuals in positions of authority and has a negative connotation because of individuals who have misused or abused power for selfish gain. In addition, the women's views of power and influence relate to the ways in which they have accepted society's ideas of how men and women should act. Men can be described as powerful, but women cannot since they are supposed to be submissive and obliging. These results seem to suggest that women and men may understand power and influence differently, and these possible gendered differences are worthy of future examination.

In addition, more research is needed to understand the complexity of how female practitioners define 'influence' and 'power.' This study sought to begin filling that gap in 
research by exploring how women gain influence/power. For practitioners, this study indicates continued challenges for new generations of female public relations practitioners who aspire to become successful, powerful communication managers. Most of the women's challenges came from trying to handle work and family responsibilities. Perhaps, by choosing to spend more time with their families or not staying late at the office, women are limiting their potential to gain influence. Notably, the women reported technology and the 'on call' nature of the PR business made it difficult for them to disconnect from work. Perhaps the younger generation of PR practitioners who are working mothers will have an ever more difficult time separating their work and home lives because of the prevalence of technology such as smartphones. Future research should continue to examine how women in public relations handle the additional challenges of raising a family while being expecting to be 'on call' at all times.

Overall, the women enjoyed their careers practicing PR in higher education and found their jobs both challenging and rewarding. Although the women remained outnumbered in the institutions' leadership teams, they said the higher-education culture in general and their institutions in particular accept and encourage women in leadership positions. As in other industries, practicing PR in higher-education institutions' presents practitioners with unique challenges for women who wish to ascend to senior-level PR management positions. This study helps fill the gap in research by addressing how female PR managers in higher-education institutions gain influence. 


\section{References}

Aldoory, L., Reber, B. H., Berger, B. K., \& Toth, E. L. (2008). Provocations in public relations: A study of gendered ideologies of power-influence in practice. Journalism \& Mass Communication Quarterly, 85(4), 735-750.

American Council on Education. (2007). The American College President: 2007 Edition 20th Anniversary. American Council on Education. ACE Fulfillment Service Department 191, Washington, DC.

Bachrach, S. \& Lawler, E. (1980). Power and politics in organizations. San Francisco: Jossey-Bass.

Ballenger, J. (2010). Women's access to higher education leadership: Cultural and structural barriers. Forum on Public Policy Online, 2010(5), 20-20. Retrieved from http://search.proquest.com/docview/854554347?accountid=14576.

Barbalet, J. M. (1985). Power and resistance. The British Journal of Sociology, 36(4), 531-548.

Berger, B. K. (2005). Power over, power with, and powerto relations: Critical reflections on public relations, the dominant coalition, and activism. Journal of Public Relations Research, 17(1), 5-28.doi:10.1207/s1532754xjprr1701_3

Berger, B.K and Reber, B. H., Gaining Influence in Public Relations: The Role of Resistance in Practice (Mahwah, NJ: Lawrence Erlbaum Associates, 2006.

Berger, B., \& Reber, B. H. (2005). Influence in Public Relations: When and Where Professionals Find It. Conference Papers -- International Communication Association, 1-26.

Bowen, S. (2007). The ethical counselor role: Strategic decision making in communication management. Conference Papers -- International Communication Association, 1.

Buzzanell, P. M. (1994). Gaining a voice: Feminist organizational communication theorizing. Management Communication Quarterly, 7, 339-383. DOI: 10.1177/0893318994007004001 (Reprinted: Putnam, L. L., \& Krone, K. J. (Eds.). (2006). Organizational communication, Five-volume set. London: Sage.) 
Buzzanell, P., Meisenbach, R., Remke, R., Liu, M., Bowers, V., \& Conn, C. (2005). The Good Working Mother: Managerial Women's Sensemaking and Feelings About Work-Family Issues. Communication Studies, 56(3), 261-285. doi:10.1080/10510970500181389

Carli, Linda. (2001). Gender and Social Influence. Journal of Social Issues, 57(4), 725741.

Conrad, C. (1983). Organizational power: Faces and symbolic form. In L. L. Putnam \& M. E. Pacanowsky (Eds.), Communications and organizations: An interpretive approach (pp. 173-194). Beverly Hills, CA: Sage.

Dougherty, D. S. (1999). Dialogue through standpoint: Understanding women's and men's standpoints of sexual harassment. Management Communication Quarterly, $12,436-468$.

Dozier, D. M. \& Gottesman, M. (1982, July). Subjective dimensions of organizational roles among public relations practitioners. Paper presented at the meeting of the Public Relations Division, Association for Education in Journalism, Athens, $\mathrm{OH}$.

Dozier, D. M., \& Grunig, L. A. (1992). The organization of the public relations function. In J. E. Grunig (Ed.), Excellence in public relations and communication management (pp. 395-417). Hillsdale, NJ: Lawrence Erlbaum Associates.

Dozier, D. M., Grunig, L. A., \& Grunig, J. E. (1995). Manager's guide to excellence in public relations and communication management. Mahwah, $\mathrm{NJ}$ : Lawrence Erlbaum Associate

Dozier, D.M., Sha, B. and Shen, H. (2012). Why women earn less than men: The cost of gender discrimination in U.S. public relations. Public Relations Journal. 7 (1).

Editorials on Rosener's (1990) “The ways women lead.” (1991). Harvard Business Review, 69, 150-160.

French, J. R. P., \& Raven, B. (1960). The bases of social power. In D. Cartwright and A. Zander (Eds.), Group dynamics (pp. 607-623). Evanston, IL: Row, Peterson.

Grunig, J. E. (Ed.). (1992). Excellence in public relations and communication management. Hillsdale, NJ: Lawrence Erlbaum Associates.

Grunig, J. E. (2006). Furnishing the edifice: Ongoing research on public relations as a strategic management function. Journal of Public Relations Research, 18(2), 151176. doi:10.1207/s1532754xjprr1802_5 
Grunig, L.E., Toth, E. L. and Hon, L.C. "Feminist Values in Public Relations," Journal of Public Relations Research 12 January, 2000): 57.

Grunig, L. A. (1992). Power in the public relations department. In J. E. Grunig (Ed.), Excellence in public relations and communication management (pp. 483-501). Hillsdale, NJ: Lawrence Erlbaum Associates.

Harding, S. (1997). Whose Science? Whose Knowledge? Thinking from Women's Lives, Cornell University Press, Ithaca, NY, 1991.

Hartsock, N. (1981). "Fundamental feminism: Prospect and perspective." In C. Bunch (Ed.), Building Feminist Theory. 32-43. New York: Longman.

Hartsock, N. (1983). The feminist standpoint: Developing the ground for a specifically feminist historical materialism." In Harding and Hintikka, 283-310.

Hay, P.D. \& Hartel, C. E. J. (2000). The influence framework: A theoretical bridge between power and organisational effectiveness. Australian journal of communication, 27(2), 131 - 154.

Heckman, S. (1997). Truth and Method: Feminist Standpoint Theory Revisited. Signs, 22(2), 341-365.

Hoffman, M. F., \& Cowan, R. L. (2010). Be careful what you ask for: Structuration theory and work/life accommodation. Communication Studies, 61(2), 205-223. doi: $10.1080 / 10510971003604026$

Hon, L. C. (1995). Toward a feminist theory of public relations. Journal of Public Relations, 7, 27-88.

Hon, L. C., Grunig, L. A., \& Dozier, D. M. (1992). Women in public relations: Problems and opportunities. In J. E. Grunig (Ed.), Excellence in public relations and communication management (pp.419-438). Hillsdale, NJ: Lawrence Erlbaum Associates, Inc.

Jones, C.B. \& Gates, M.(2004). Gender-based wage differentials in a predominantly female profession: Observations from nursing. Economics of Education Review, $23,6,615-631$.

Kanter, R. M. (1976). The impact of hierarchical structures on the work behavior of women and men. Social Problems, 23, 415-430.

Kanter, R. M. (1977). Men and women of the corporation. New York: Basic Books. 
Keyton, J. (2006). Communication research: Asking questions, finding answers ( $2^{\text {nd }}$ ed.). New York: McGraw-Hill.

LaClau, E. \& Mouffe, C. (1985). Hegemony and socialist strategy. London: Verso.

Lauzen, M. M, \& Dozier, D. M. (1992). The missing link: The public relations manager role as a mediator of organizational environments and power consequences for the function. Journal of Public Relations Research, 4, 205-220.

Lindolf, T.R (1995). Qualitative communication research methods. Thousand Oaks, CA: Sage.

Lindlof, T.R., \& Taylor, B.C. (2002). Qualitative communication research methods ( $2^{\text {nd }}$ ed.). Thousand Oaks, CA: Sage.

Marshall, C. \& Rossman, G.B. (1995). Designing qualitative research $\left(2^{\text {nd }} \mathrm{ed}.\right)$. Thousand Oaks, CA: Sage.

Mintzberg, H. (Ed.). (1983). Power in and around organizations. Englewood Cliffs, NJ: Prentice- Hall.

O’Neil, J. (2003). An investigation of the sources of influence of corporate public relations practitioners. Public Relations Review, 29(2), 159. doi:10.1016/S03638111(03)00016-X

Owen, W.F. (1984). Interpretative themes in relational communication. Quarterly Journal of Speech, 70, 274-287.

Pompper, D. (2007). The Gender-Ethnicity Construct in Public Relations Organizations: Using Feminist Standpoint Theory to Discover Latinas' Realities. Howard Journal Of Communications, 18(4), 291-311. doi:10.1080/10646170701653669

Pfeffer, J. (1992). Managing with power: Politics and influence in organizations. Boston: Harvard Business School Press.

Place, K. R. (2012). Power-Control or Empowerment? How Women Public Relations Practitioners Make Meaning of Power. Journal Of Public Relations Research, 24(5), 435-450. doi:10.1080/1062726X.2012.723278

Powell, W. W. (1990). Neither market nor hierarchy: Network forms of organization. Research in organizational behavior, 12, 295-336. 
Rakow, L. "From the Feminization of Public Relations to the Promise of Feminism," in Beyond the Velvet Ghetto, ed. Elizabeth L. Toth and Carolyn G. Cline (San Francisco: IABC Research Foundation, 1989), 287-98; 289.

Salancik, G. R., \& Pfeffer, J. (1977, Winter). Who gets power--and how they hold on to it: A strategic-contingency model of power. Organizational Dynamics, 5, 3-21.

Sallot, L. M., Cameron, G., \& Weaver-Lariscy, R. (1998). PR educators and practitioners identify professional standards. Journalism \& Mass Communication Educator, 53(2), 19-30.

Sha, B. (2011, March 8) PR women: New data show gender-based salary gap is widening. Ragan's PR Daily. Retrieved April 21, 2013, from http://prdaily.com/Main/Articles/7468.aspx.

Sheppard, D. L. (1989). Organizations, power and sexuality: The image and self-image of women managers. In J. Hearn, D.L. Sheppard, P. Tancred-Sheriff, \& G. Burrell (Eds.), The sexuality of organization (pp. 139-157). London: Sage.

Smith, E., \& Grenier, M. (1982). Sources of organizational power for women: Overcoming structural obstacles. Sex Roles, 8, 733-746.

Spicer, C. (1997). Organizational public relations: A political perspective. Mahwah, NJ: Lawrence Erlbaum Associates, Inc.

Stivers, C. (2002). Gender images in public administration: Legitimacy and the administrative state $\left(2^{\text {nd }}\right.$ ed.). Thousand Oaks, CA: Sage.

Tam, S. Y., Dozier, D. M., Lauzen, M. M., \& Real, M. R. (1995). The impact of superiorsubordinate gender on the career advancement of public relations practitioners. Journal of Public Relations Research, 7, 259-272.

Toegel,G. (2011, Feb. 18). Disappointing statistics, positive outlook. Forbes. Retrieved April 21, 2013, from http://www.forbes.com/2011/02/18/women-businessmanagement-forbes-woman-leadership-corporate-boards.html.

Toth, E. L., Serini, S. A., Wright, D. K., Emig, A. G. (1998). Trends in public relations roles: 1990-1995. Public Relations Review, 24(2), 19-29.

Weaver-Lariscy, R.A., Sallot, L.M., \& Cameron, G.T., (1996), Justice and Gender: An Instrumental and Symbolic Explication. Journal of Public Relations Research, 8(2): 107-121.

Weaver-Lariscy, R., Cameron, G. T., \& Sweep, D. D. (1994). Women in Higher Education Public Relations: An Inkling of Change?. Journal Of Public Relations Research, 6(2), 125-140. 
White, K., Riordan, S., Ozkanli, O., \& Neale, J. (2010). Cross cultural perspectives of gender and management in universities. South African Journal of Higher Education, 24(4), 646-660. Retrieved from http://search.proquest.com/docview/898324903?accountid=14576

Williams, C. L. (1992). The glass escalator: Hidden advantages for men in the "female" professions. Social Problems, 39 (3), 253-267. Retrieved from http://www.jstor.org.proxy.mul.missouri.edu/stable/3096961

Wood, J.T. (1997). Communication Theories in Action, Wadsworth, Belmont, CA.

Wood, J.T. (1995). "Feminist Scholarship and the Study of Relationships," Journal of Social and Personal Relationshps, Vol. 12, p. 110.

Wood, J. T. (1992). Telling our stories: Narratives as a basis for theorizing sexual harassment. Journal of Applied Communication Research, 20, 349-362.

Wood, J. T., \& Conrad, C. (1983). Paradox in the Experiences of Professional Women. Western Journal Of Speech Communication: WJSC, 47(4), 305-322. 


\section{APPENDIX}

\section{Questions for Female Public Relations Managers}

1. Tell me about your career journey and how you arrived at your current position.

2. Tell me about what helped you climb the career ladder.

3. Tell me about your biggest challenge to climbing the career ladder.

PROBE: What are the differences or similarities for women in climbing the career ladder in higher education compared to other areas where PR is practiced?

4. Tell me about other women communicators in your institution who didn't/haven't moved up the career ladder.

5. What would you say leads to gaining influence in your workplace?

6. Please tell me about a time at work when you used your power, or influence, or when you felt powerful or influential.

PROBE: Are there any specific personal characteristics a PR practitioner would need to gain influence? If so, which ones? Can you give me an example of when someone's personality has helped him or her influence a situation?

PROBE: Would you say PR practitioners would need specific knowledge or skills to gain influence? If so, what kind of knowledge or which skills would practitioners use to gain influence? Can you give me an example of when someone has used his or her knowledge or skills to influence a situation?

7. Can you tell me about a time when other people's power or influence was used against you or to limit your success?

PROBE: When a PR manager has power, or influence, is it related to possessing certain resources? If so, which ones? Can you give me an example of when someone has used resources to influence a situation?

PROBE: Does having access to or control over information give individuals power? Can you give me an example of when someone used access to or control over information to influence a situation?

PROBE: When a PR manager has power, or influence, is it related to their formal position in the organizational hierarchy? If so, can you give me an example of when someone has used his or her job rank to influence a situation? 
PROBE: When a PR manager has power, or influence, is it related to being able to give punishments or rewards? If so, how? Can you give me an example of when someone used punishments or rewards to influence a situation?

8. What are some specific skills that give women power or influence?

PROBE: How might women and men use power or influence similarly?

9. What sort of advice would you give to women entering public relations who aspire to become communication managers?

PROBE: Is there any advice you would give young women that would be different from advice you would offer young men?

10. Are there any other thoughts or comments you would like to add?

\section{Biographical:}

Job Title:

Years of Industry Experience:

Age:

Marital Status:

Number of children:

Ages of children:

Type of university: (public, private, etc.) 